\title{
Is the Value of the New Business Tax Shield Lower? Comparative Study of International Valuation Methods
}

\author{
Lucia Michalkova ${ }^{1, *}$, Katarina Frajtova Michalikova ${ }^{2}$ \\ ${ }^{1}$ Department of Economics, Faculty of Operation and Economics of Transport and Communications, \\ University of Zilina, Univerzitna 1, 01026 Zilina, Slovakia \\ ${ }^{2}$ Department of Economics, Faculty of Operation and Economics of Transport and Communications, \\ University of Zilina, Univerzitna 1, 01026 Zilina, Slovakia
}

\begin{abstract}
The macroeconomic environment has been characterized by strong GDP growth in recent years. The favourable conditions allow the growth of new innovative businesses (start-ups), which support multiplier economic development. New businesses are often unprofitable in the first years of existence; there is a higher probability of default. The issue of startups may be insufficient funding, high costs of financial distress and resulting low corporate value and unattractiveness for investors. The aim of this paper is to analyse and evaluate which of the existing methods of quantifying the debt tax shield is suitable for start-ups. Three different approaches have been chosen to calculate the interest tax shield; Modigliani-Miller (1963) model for imperfect capital markets and two models from Velez-Pareja $(2013,2016)$. The results were obtained by correlation analysis of more than 5,000 Slovak businesses, the impact of the age of the business on the value of tax shield was examined. Also, the impact of the industry on the value of tax shield was explored. The results of the analysis suggest that the quantification by Modigliani-Miller (1963) formula does not take sufficient into account of the age of company. In contrast, the Velez-Pareja (2013, 2016) models are suitable for start-ups, because they take into account the potential tax shield, which occurs when the operating income cannot cover financial costs (especially interest paid). In innovative industries, start-ups often do not reach the traditional tax shield, but their value may be higher using an alternative formula by Velez-Pareja.
\end{abstract}

\section{Introduction}

Financial management of a company is subordinated to the fulfilment of the basic business objective, maximizing profit. This objective takes into account, in particular, the interests of business owners. A better measure than profit is cash flow, which is directly linked to liquidity and the Going Concern criterion [1]. However, investors are also interested in risk in addition to cash flow. The role of the financial manager is to find the appropriate balance

\footnotetext{
* Corresponding author: lucia.michalkova@fpedas.uniza.sk,
} 
between cash flow and risk to make the business to shareholders and investors as attractive as possible $[2,3$.

The capital structure of a company has a significant impact on the achievement of the primary business objective; a well-established debt-to-equity ratio can increase the value of a business and reduce financial risk. The tax shield arises from the deductibility of interest paid and increases the value for shareholders. A prerequisite for applying this tax advantage is to make a non-zero profit before tax.

Businesses at the start of their life cycle (start-ups) often do not make a positive pre-tax profit and therefore cannot optimally use the interest tax shield. They mainly use internal financing sources, but they may not be sufficient to finance the company's growth potential. $[4,5]$

Acquisition of new investors (venture capital investors) is conditional on correct valuation of the company. A suitably quantified value of the interest tax shield increases the value of the business and thus the shareholder value. High business value predetermines greater attractiveness for investors and improves conditions for IPO.

\section{Literature review}

\subsection{Valuation of tax shield}

According to Brealey, Myers and Allen [6], an interest tax shield is defined as: tax savings resulting from deductibility of interest payments. In Damodaran [7] the interest tax shield is expressed in a similar vein: Interest is tax-deductible, and the resulting tax savings reduce the cost of borrowing to firms.

Taking into account the tax system, according to Modigliani and Miller [8], interest as a tax deductible expense affects the pre-tax profit and hence the amount of tax liability of the company. It follows that even the value of company will change due to the existence of an interest tax shield. The value of tax shield is simply given as a product:

$$
T S=T \cdot k_{D} \cdot D
$$

where TS - value of tax shield, $T$ - corporate tax rate, $k_{D}$ - cost of debt, $D$ - market value of debt.

A necessary condition for non-zero value of tax shield is positive profit before tax that covers the interest paid.

In addition to the method of quantification of interest tax advantage in Eq. (1) there are also four different formulations of the value of tax shield. If the debt is constant and perpetual, the company's tax shield depends only on the corporate tax rate and the value of debt. Hence, the present value of tax shield equals the discounted value of Eq. (1). As the discount factor, the cost of debt $k_{D}$ is used, since the risk of the tax shield (hereinafter TS) should be the same as the risk of interest paid.

$$
P V(T S)=\frac{T \cdot k_{D} \cdot D}{k_{D}}=T \cdot D
$$

where $P V(T S)$ is the present value of interest tax shield.

The previous Eq. (1) and (2) show that the tax shield is affected by three variables: corporate tax rate; cost of debt and the value of debt (the market value of debt). Velez-Pareja [9] argued, that the main source of tax savings is interest and EBIT and other income (OI) is less than the amount of financial expenses $(F E)$, the company does not pay corporate income tax. Nevertheless it generates the partial tax shield. Another possible scenario occurs if the sum of EBIT and $O I$ is negative. Tax savings do not arise because the company does not pay any tax. In sum, all possible cases are given in Eq. (3).

$$
T S=\operatorname{Maximum}(T \times \operatorname{Minimum}(E B I T+O I, F E), 0)
$$


This is significance for further research; most of the literature dealing with the issue of tax shields is based on Eq. (2). It also means that both new businesses and start-ups can achieve partial tax savings, despite the fact that EBIT and $O I$ cannot cover the value of financial expenses.

Calculation of the value of tax shield is not only based on the interest, but in practice it is much more complicated. If the loss carried forward is allowed, according to Velez-Pareja [10] the tax shield does not reduce the tax liability in just one period, but its part is transferred to another future period when the loss is carried forward. In simplified terms, the value of tax shield is equal to the formula

$$
T S=\operatorname{Maximum}\left(T \cdot \operatorname{Minimum}\left(E B I T_{a d j}, F E+L C F_{t}-L C F_{t-1}\right), 0\right)
$$

where $L C F_{t-1}$ or $L C F_{t}$ is loss carried forward at period $t(t-1)$ and $E B I T_{a d j}$ is EBIT plus other income $(O I)$.

These definitions of the tax shield are contradictory and give different perspectives on its value. Obviously, the value of the tax shield depends on many factors in the business; the Velez-Pareja model has a clear relationship between the value of the tax shield and the operating profit. However, it is necessary to determine whether there is a relationship between EBIT and the value of a tax shield quantified according to other formulas.

\subsection{Sources of funding during the business life cycle}

Life cycle models depict stages of business development as a sequence of different stages that depend on each other. There are several business life cycle models; they are divided according to their focus on managerial types of models and models focused on operational and financial aspects. We have adapted the model by Dickinson [11], which recognize 5 basic stages: Introduction (Launch), Growth, Maturity, Shake-out and Decline.

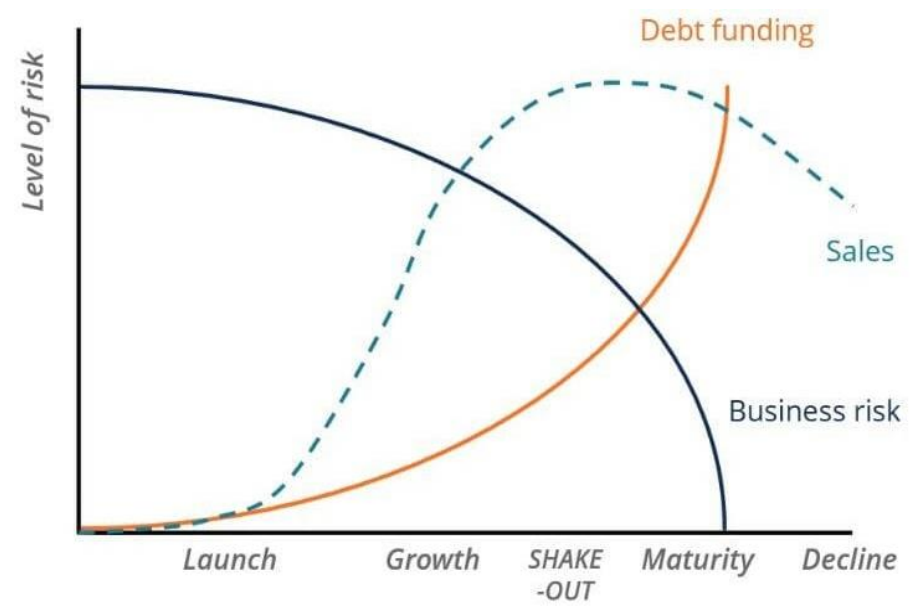

Fig. 1. Corporate financial cycle (source [12])

The financial position of the company in individual phases of the life cycle predetermines the capital structure of the company. Pecking-order theory describes that companies tend to be financed by internal resources, followed by debt and then by equity. In the growth phase, an enterprise uses debt more than equity; on the contrary, mature firms prefer equity. In the Decline phase, the debt level is rising again. The following Fig. 1 illustrates the corporate financial cycle.

There is business risk on the vertical axis; this includes the risk of providing capital irrespective of the provider (debt holders or shareholders). There are basic life cycle stages 
on the horizontal axis; the necessary financial indicators for analysis are sales, debt and business risk.

An enterprise in the Launch stage has high cash outflows due to investment and operating activities. Conversely cash inflows are mainly due to external funding from shareholders [13]. Investments in working capital increase sales growth. . Business risk is highest. There is a lag between revenue growth and profit growth [14]. It may therefore be more and more financed by debt.

Growth stage is characterized by rapid growth in sales and business reaches break-even point; business risk is reduced. Profit still lags behind sales; it does not reach the maximum value. Production capacity is growing and operating cash flow is positive [15]. Therefore, the total cash flow is also positive. The company becomes profitable and can obtain debt with lower cost of debt. In addition to short-term loans, companies may also obtain long-term debt.

In the Shake-out phase enterprise sales keep growing, but at a lower rate. The market is saturated and sales reach maximum value. This causes an exponential increase in debt and a decrease in business risk. The company has excellent financial health and good ability to pay its debt. Profit starts to decline due to cost increases. Investment and financial outflows arise from the obsolescence of investments and the distribution of surplus funds [16]. The value of working capital is reduced, resulting in growth of operating cash flow. Altogether, the total cash flow is positive and exceeds the profits.

Mature business achieves maximum revenue, but cash flow is relatively stable to stagnant. The main expenses of the company are much lower than revenues; therefore cash flow significantly exceeds profit. Business risk is negatively correlated with sales to the extent that business risk is eliminated. Therefore, the company has the easiest access to debt financing. At this stage, an enterprise can extend its life cycle by investing in new technologies or relocating to new markets.

In the final stage of "Decline" corporate sales, profit and cash flow are declining. Operating cash flow is negative, while investment cash flow is positive due to declining growth rates or asset divestments [17]. Business risk (especially credit risk) is of an increasing nature as it reduces the ability of an enterprise to pay its debts by operating profit. The company is trying to reduce its debt (not shown in Fig. 1). The cost of capital increases due to the increase in credit risk and shareholders' expectations. Financial cash flow may be negative or positive with respect to whether the debts are repaid or negotiated.

From the foregoing it is clear that debt financing is intended more for businesses in the higher stages of the life cycle. Conversely, young businesses are exposed to high business risk, eliminating their ability to obtain cheaper debt than equity. Pinkova and Kaminkova [20] report that, based on their research, businesses in the Czech Republic have a higher debtto-equity ratio in all life cycle phases except the Maturity phase. Mature companies have more internal equity resources. This result is in line with the Pecking-order theory. New and growing businesses have debts, but mostly short-term. Young businesses and start-ups use various alternative forms of financing that, in addition to capital; can also add value to the business (business angels, venture capital, grants, etc.).

Businesses finance their activities by debt mainly from the growth stage; one of the conditions for more favourable debt financing it is to reach a break-even point. Once a business makes a non-zero profit and has sufficient collateral, its credit rating will increase. Some forms of debt financing may also use start-ups, their amount is limited.

The life cycle stage affects the company's capital structure and profitability; thus the value of the tax shield. This implies that young businesses should not have sufficient operating profits to pay interest and their debt should be lower due to high business risk. The value of the tax shield should be low or zero compared to older and mature businesses. Therefore, it is important to determine how the age of an enterprise affects the tax shield and thus the value of the enterprise. 


\section{Methods}

The aim of this paper is to analyse and determine which method of quantifying the value of the tax shield is suitable for young businesses and start-ups. The previous chapter shows that the life cycle stage (business age) and profit significantly affect the value of the tax shield. Correlation analysis is a suitable method for investigating these relationships. To confirm the relationship between the variables, we used the correlation coefficient significance test. [19].

In this study, on the one hand, we quantified the value of the tax shield. Three models of tax shield value quantification were selected: Modigliani and Miller [8] for imperfect capital markets mentioned in Brealey, Myers and Allen [6] and two models from Velez-Pareja $[9,10]$. The formulas for their quantification are given in Eq. (2) - (4). Two variables were selected as dependent variables: company age and operating profit. The correlation analysis indicators together with their formulas are summarized in Table 2.

Table 1. Correlation analysis variables and formulae

\begin{tabular}{|c|c|c|}
\hline Variable/model & Label & Algorithm \\
\hline $\begin{array}{l}\text { Modigliani and } \\
\text { Miller (1963) }\end{array}$ & $\mathrm{TS}_{\text {MM }}(1963)$ & $T S=T \cdot k_{D} \cdot D$ \\
\hline Velez-Pareja (2013) & $\mathrm{TS}_{\mathrm{VP}}(2013)$ & $T S=\operatorname{Maximum}(T \times \operatorname{Minimum}(E B I T+O I, F E), 0)$ \\
\hline Velez-Pareja (2016) & TSVP (2016) & $\begin{array}{c}T S=\operatorname{Maximum}\left(T \cdot \operatorname{Minimum}\left(E B I T_{a d j}, F E+L C F_{t}\right.\right. \\
\left.\left.-L C F_{t-1}\right), 0\right)\end{array}$ \\
\hline Operating profit & EBIT & $E B I T=E A T+$ Tax + Interest paid \\
\hline Company's age & AGE & $A G E=$ Present year - Company's year of birth \\
\hline
\end{tabular}

In addition to the age of the business, the value of the tax shield is also affected by the business sector. NACE categorization is selected as an appropriate indicator of the sector. The tax shield value model, which is most sensitive to the age of the company, was chosen as a dependent variable. Analysis of variance (ANOVA) is considered suitable for investigating the influence of qualitative variables on quantitative variable. The method can only be used if the necessary assumptions are met (all subsets studied are normally distributed, homogeneity of variations and case independence).

If all the assumptions for the use of $A N O V A$ are fulfilled, the hypothesis of equivalence of the mean values is tested itself. Analysis of variance is based on examination of variance between groups and within groups. The null hypothesis in this case is $\mathrm{H}_{0}: \mu_{1}=\mu_{2}=\mu_{3}=$ $\cdots=\mu_{k}$ and $\mathrm{H}_{1}$ is non $\mathrm{H}_{0}$.

If the null hypothesis is rejected, it should be decided that there are pairs of mean values that are not equal. Therefore, post-hoc tests should be used to determine which pairs have different mean values. There are several methods to test to find out which pairs of means are significant, Scheffé's method is chosen.

\section{Results and discussion}

The study data was collected from the Amadeus database, which collects business data from businesses across Europe. The sampling criteria are in line with the criteria for the existence of a tax shield: the main criterion was the non-zero value of the interest paid. In models based on the MM model, the second criterion is positive pre-tax profit. Given that the Velez-Pareja [10] model assumes a loss carried forward, the second criterion was not applied. If the pretax profit was zero or negative, then the MM tax shield was zero. The third selection criterion was the registered office in Slovakia. 9600 enterprises were selected and the data cover the year 2018.

First of all, companies with incomplete financial statements were removed from the sample. The second step was to remove outliers using the interquartile range. Net sample 
contained data on 5124 Slovak companies. Table 3 shows the descriptive statistics of the examined variables.

Table 2. Descriptive statistics of variables

\begin{tabular}{|c|r|c|r|r|r|r|}
\hline Variable & \multicolumn{1}{|c|}{ Mean } & \multicolumn{1}{c|}{ Std Dev } & \multicolumn{1}{c|}{ Minimum } & Maximum & \multicolumn{1}{c|}{ Mode } & \multicolumn{1}{c|}{ N } \\
\hline TS MM (1963) & 1507,89 & 20975,77 & 0 & 1808970 & 0 & 5124 \\
\hline TS VP (2013) & 854,855 & 3682,32 & 0 & 173925,1 & 0 & 5124 \\
\hline TS VP (2016) & 774,467 & 3627,21 & 0 & 173925,1 & 0 & 5124 \\
\hline AGE & 8,432 & 4,799826 & 2,6611111 & 21 & 6 & 5124 \\
\hline EBIT & 37634,87 & 214559,2 & -1327939 & 3852720 & 1520 & 5124 \\
\hline
\end{tabular}

The results from Table 2 indicate that the highest value of the tax shield is achieved by enterprises when using the Modigliani and Miller model (1963), almost twice as large as for the models from Velez-Pareja [9] and [10]. In all three cases, the minimum value is the most common (modal) value. This means that a significant proportion of the sample is held by companies that do not receive the interest tax advantage or the partial tax advantage examined in the Velez-Pareja models.

The second step of the analysis is to test hypotheses about the relationship between the tax shield, the age of the company and operating profit. In the following correlation matrix (Table 3), null hypotheses about the insignificance of correlation coefficients are tested; the given p-value is 0.05 .

Table 3. Correlatiom matrix of tax shield models, age of company a operating profit

\begin{tabular}{|c|c|c|c|}
\hline \multicolumn{4}{|c|}{$\begin{array}{c}\text { Pearson Correlation Coefficients, } \mathbf{N}=\mathbf{5 1 2 4} \\
\text { Prob }>\mid \text { r }\end{array}$} \\
\hline & under H0: Rho= \\
\hline \multirow{2}{*}{ AGE } & TS Mm (1963) & TS vP (2013) & TS vP (2016) \\
\cline { 2 - 4 } & 0.02738 & 0.04527 & 0.03976 \\
\hline \multirow{2}{*}{ EBIT } & 0.0092 & $<.0001$ & 0.0002 \\
\cline { 2 - 4 } & 0.05306 & 0.23417 & 0.22997 \\
\hline
\end{tabular}

Based on the correlation coefficients of the two variables examined, we found that the Velez-Pareja models [9] and [10] correctly estimate the value of the interest tax shield in accordance with the age of the company. At the same time, the value of the tax shield increases with the increase in operating profit. The increase in operating profit is related to the change in business (operating and credit) risk as shown in Figure 1. This is, according to Velez-Pareja [20], given that the tax shield is subject to three types of risk: risk of default in debt, if the enterprise is able to pay tax but is unable to pay interest; market cost of debt risk (arises when the contractual interest rate is linked to a market interest rate) and operational risk. The operational risk is directly imported into the Velez-Pareja [9] and Velez-Pareja [10] models, unlike the Modigliani and Miller [8] model, which does not directly reflect operational risk.

The third step of the analysis is the examination of the impact of industry on the value of the tax shield. Based on the correlation analysis we have chosen the model with the largest correlation coefficients; Velez-Pareja [9] model. Firstly we tested the first assumption ANOVA, testing normality subsamples (enterprises in sectors according to NACE classification). According to Kolmogorov-Smirnov test, we reject the null hypothesis of 
normality subsets. Subsequently, we used the nonparametric Kruskal-Wallis test, whose results are described in Table 4.

Table 4. Kruskal-Wallis test of industry impact on the value of tax shield

\begin{tabular}{|c|c|}
\hline \multicolumn{2}{|c|}{ Kruskal-Wallis Test } \\
\hline Chi-Square & 238.4877 \\
\hline DF & 18 \\
\hline Pr $>$ Chi-Square & $<.0001$ \\
\hline
\end{tabular}

The P-value of the Kruskal-Wallis test is less than a significance level of 0.05 , which means that the null hypothesis of median equality has been rejected. Subsequently, we tested which mean value pairs are different; ie which sectors have a significantly different value of tax shield than other sectors. By Scheffe method value of the tax shield in a NACE A Electricity, Gas, Steam and Air Conditioning Supply is significantly different from almost all sectoral averages tax shield in addition to the three sectors.

We can conclude that the industry's impact on the value of the tax shield is very weak, contrary to the results of Kemsley and Nissim [21] for US businesses. On the contrary, the impact of age is more pronounced and the most significant effect on the value of the tax shield has the operating profit and the resulting risk.

\section{Conclusion}

The value of the tax shield is a significant element of the company's value and share value. In the short term, the tax shield is one of the earnings management elements. Therefore, it is important to know the factors that affect the tax shield and to determine which of the tax shield models best describes the financial position of the company at different stages of its life cycle [22].

In the paper we analysed the impact of age and operating profit $(E B I T)$ on the value of the tax shield. Three models of the tax shield were used: the traditional model of Modigliani and Miller [8] and two models by Velez-Pareja [9] and [10]. Based on the correlation analysis, we can conclude that both Velez-Pareja models show a positive correlation with company age and operating profit and are suitable for quantifying the value of the tax shield in the first stages of the life cycle. This means that older businesses achieve a higher tax shield and younger businesses can achieve a non-zero tax shield in terms of a partial tax shield or carry over the value of the tax shield to future years. In addition, the lower value of the tax shield in the first years of the company's existence confirms the impact of business (operational) risk on the tax shield.

In addition, we analysed the impact of the industry on the value of the tax shield. We found that the impact of this factor is not significant, only NACE D companies have significantly different tax shield values.

The paper is an output of the scientific project VEGA 1/0210/19: Research of innovative attributes of quantitative and qualitative fundaments of the opportunistic earnings modeling.

\section{References}

1. T., Kliestik, M. Kovacova, I. Podhorska, J. Kliestikova, Searching for Key Sources of Goodwill Creation as New Global Managerial Challenge. Polish Journal of Management Studies 17, 1, 144-154 (2018) 
2. P. Kral, K. Janoskova, Condition Of Acceptability Of Project Risk In Management Of The Project Portfolio, in 15th International Scientific Conference on Globalization and its Socio-Economic Consequences, Rajecke Teplice, 345-352 (2015)

3. K. Valaskova, V. Bartosova, P. Kubala, Behavioural Aspects of the Financial DecisionMaking. Organizacija, 52, 1, 22-32 (2019)

4. M. Banaszewska, The determinants of local public investments in Poland. Equilibrium Quarterly Journal of Economics and Economic Policy, 13, 1, 105-121 (2018)

5. J. Olah, G. Karmazin, D. Mate, J. K. Grabara, J. Popp The effect of acquisition moves on income, pre-tax profits and future strategy of logistics firms. Journal of International Studies, 10, 4, 233-245 (2017)

6. R.A. Brealey S.C. Myers, F. Allen, Principles of corporate finance, 10th ed., New York: McGraw-Hill/Irwin (2010)

7. A. Damodaran, Applied Corporate Finance. 3rd ed. New York: John Wiley \& Sons (2010)

8. F. Modigliani, M.H. Miller, Corporate income taxes and the cost of capital. A correction. The American Economic Review, 53, 3, 433-443 (1963)

9. I. Velez - Pareja, Return to Basics: Are You Properly Calculating Tax Shields? Análisis Financiero, 122, 6-17 (2013)

10. I. Velez-Pareja, Tax shield, financial expenses and losses carried forward. Cuadernos de Economics, 35, 69, 663- 689 (2016)

11. V. Dickinson, Cash flow patterns as a proxy for firm life cycle. The Accounting Review, 86, 6, 1969-1994 (2011)

12. What is the Business Life Cycle?, accessed on: Sep. 10, 2019 [Online]. Available: https://corporatefinanceinstitute.com/resources/knowledge/finance/business-life-cycle/

13. M. Jensen, The agency costs of free cash flows, corporate finance, and takeovers. American Economic Review, 76, 2, 323-329 (1976)

14. J. Yoo, S. Lee, S. Park, The Effect of Firm Life Cycle on the Relationship between R\&D Expenditures and Future Performance, Earnings Uncertainty, and Sustainable Growth. Sustainability, 11, 8, 1-19 (2019)

15. P.M. Kort, S. Wrzaczek, Optimal firm growth under the threat of entry. European Journal of Operational Research, 246, 1, 281-292 (2015)

16. B. Jovanovic, Selection and the Evolution of Industry. Econometrica, 50, 3, 649-670 (1982)

17. A. Akbar, M. Akbar, W. Tang, M.A. Qureshi, Is Bankruptcy Risk Tied to Corporate Life-Cycle? Evidence from Pakistan. Sustainability, 11, 3, 1-22 (2019)

18. P. Pinkova, P. Kaminkova, Corporate life cycle as determinant of capital structure in companies of Czech automotive industry. Acta Universitatis Agriculturae et Silviculturae Mendelianae Brunensis, 60, 2, 255-259 (2011)

19. R. Stoklasova, Econometric analysis of SMEs in Eurozone. Forum Scientiae Oeconomia, 6, 1, 19-29 (2018)

20. I. Velez-Pareja, Risky Tax Shields: An Exploratory Study. Cuadernos de Administración, 23, 41, 213-235 (2010)

21. D. Kemsley, D. Nissim, Valuation of the Debt Tax Shield. The Journal of Finance, 57, 5, 2045-2073 (2002)

22. V. Tretyak, Economic performance assessment for agricultural market in a region: Evidence from Russia. Ekonomicko-manazerske spektrum, 12, 1, 83-93 (2018) 